\title{
Cyclic variation of $F$ prostaglandins in the uterine fluids of the cow
}

\author{
P. Lamothe, D. Bousquet and P. Guay \\ College of Veterinary Medicine, University of Montreal, C.P. 5000, \\ Saint-Hyacinthe, Quebec, Canada
}

A number of reports have indicated that prostaglandins (PGs) of the F series are present in the blood plasma (Bland, Horton \& Poyser, 1971; Blatchley, Donovan, Horton \& Poyser, 1972; Thorburn, Cox, Currie, Restall \& Schneider, 1972; Nancarrow et al., 1973; Peterson, Fairclough, Payne \& Smith, 1975; Shemesh \& Hansel, 1975) and uterine tissue (Wilson, Cenedella, Butcher \& Inskeep, 1972; Levitt, Tobon \& Josimovich, 1975; Shemesh \& Hansel, 1975) of many species and in the uterine fluid of non-pregnant ewes (Harrison, Heap, Horton $\&$ Poyser, 1972). The uterine glands are able to metabolize actively several substances because many components have a higher concentration in the uterine fluid than in the blood (Lamothe \& Guay, 1970; Schultz, Fahning \& Graham, 1971). Shemesh \& Hansel (1975) gave the values of PGF in the bovine endometrium but the PGF content of the uterine fluid of the cow has not been investigated throughout the oestrous cycle.

The uterine fluids (62 samples) of 29 cows (Holstein) were collected at Days 0 (oestrus), 5, 10 and -1 of the oestrous cycle. The technique of uterine fluid collection by flushing was as described by Lamothe \& Guay (1970). The volume of the collected secretions varied from 1.5 to $5.0 \mathrm{ml}$ according to the stage of the cycle, the larger volumes being obtained at Day 10 of the cycle. After freeze drying the uterine fluids were stored at $-20^{\circ} \mathrm{C}$ until extraction and separation of PGF were performed by the method of Orczyk \& Behrman (1972). The extraction was performed on silicic acid columns (average recovery $80 \%$ ) and fractions containing PGF were assayed by radioimmunoassay with the reagents supplied by Calbiochem (La Jolla, California).

The results are shown in Table 1. Highest concentrations of PGF were found at pro-oestrus (Day -1) and Day 10 of the cycle. A non-orthogonal analysis of variance showed that the values on Days 10 and -1 were significantly higher $(P<0.01)$ than those on Days 0 and 5 .

Table 1. The mean ( \pm S.E.M.) PGF content (ng/100 $\mathrm{mg}$ freeze-dried fluid) in uterine fluids of cows at different stages of the oestrous cycle

\begin{tabular}{lcccc}
\hline Day of cycle & -1 & 0 & 5 & 10 \\
No. of samples & 12 & 13 & 20 & 17 \\
PGF conc. & $71 \cdot 1 \pm 19 \cdot 4$ & $18 \cdot 3 \pm 6 \cdot 6$ & $22 \cdot 6 \pm 4 \cdot 1$ & $61 \cdot 5 \pm 13 \cdot 2$ \\
\hline
\end{tabular}

This preliminary study suggests that the concentration of PGF in the uterine secretions of cows varies cyclically, the highest values being observed during the period of luteolysis of the corpus luteum. The uterine secretions were sampled only once at each period, and it was therefore impossible to evaluate whether variations are present within the same day, as has been reported for concentrations in the plasma of ewes (Thorburn et al., 1972), but it was of interest that the range of concentrations was greater as the mean value increased (Table 1).

The PGF concentrations in the uterine fluid and in the endometrium appear to follow the same pattern during the oestrous cycle, those in the endometrium of the cow also being higher before oestrus (Shemesh \& Hansel, 1975). The results suggest that the luteolysis of the corpus luteum is associated with an increase of PGF in uterine fluids. 


\section{References}

Bland, K.P., Horton, E.W. \& Poyser, N.L. (1971) Levels of prostaglandin $F_{2 a}$ in the uterine venous blood of sheep during the oestrous cycle. Life Sci. $10,509-517$.

Blatchley, F.R., Donovan, B.T., Horton, E.W. \& POYSER, N.L. (1972) The release of prostaglandin and progestin into utero-ovarian venous blood of guinea pig during the oestrous cycle and following oestrogen treatment. J. Physiol., Lond. 223, 69-88.

Harrison, F.A., Heap, R.B., Horton, E.W. \& Poyser, N.L. (1972) Identification of prostaglandin $F_{2 \alpha}$ in uterine fluid from the nonpregnant sheep with an auto-transplanted ovary. J. Endocr. 53, 215-222.

LAMOTHE, P \& GuAY, P. (1970) Electrolytes des sécrétions intra-utérines bovines lors d'infertilité sine materia. Can. J. comp. Med. 34, 167-175.

LevitT, M.J., Tobon, H. \& Josimovich, J.B. (1975) Prostaglandin content of human endometrium. Fert. Steril. 26, 296-300.

Nancarrow, C.D., Buckmaster, J., Chamley, W., Cox, R., Cumming, I.A., Cummins, L., Drinan, J.P., Findlay, J.K., Goding, J.R., RESTAll, B.J., SCHNeIDER, W. \& THORBURN, G.D. (1973) Hormonal changes around oestrus in the cow. $J$. Reprod. Fert. 32, 320-321.
ORCZYK, G.P. \& BehrmaN, H.R. (1972) Ovulation blockade by aspirin or indomethacin. In vitro evidence for a role of prostaglandin in gonadotrophin secretion. Prostaglandins 1, 3-20

Peterson, A.J., Fairclough, R.J., Payne, E. \& Smith, J.F. (1975) Hormonal changes around bovine luteolysis. Prostaglandins 10, 675-684

Schultz, R.H., Fahning, M.L. \& Graham, E.F. (1971) A chemical study of uterine fluid and blood serum of normal cows during the oestrous cycle. J. Reprod. Fert. 27, 355-367.

Shemesh, M. \& HANSEL, W. (1975) Levels of prostaglandin $F$ (PGF) in bovine endometrium, uterine venous, ovarian arterial and jugular plasma during the estrous cycle. Proc. Soc. exp. Biol. Med. 148, 123-126.

Thorburn, G.C., Cox, R.I., Currie, W.B., Restall, B.J. \& Schneider, W. (1972) Prostaglandin F concentration in the utero-ovarian venous plasma of the ewe during the oestrous cycle. J. Endocr. 53, 325-326.

Wilson, L., Cenedella, R.J., Butcher, R.L. \& INSKEEP, E.K. (1972) Levels of prostaglandins in the uterine endometrium during the ovine estrous cycle. J. Anim. Sci. 34, 93-99.

Received 10 January 1977 